\title{
EFFECT OF SUPPLEMENT GREEN TEA AND TETRACYCLINE ON NUTRIENT DIGESTIBILITY, SOME BLOOD METABOLITES AND GROWTH PERFORMANCE OF GROWING BUFFALO CALVES
}

\author{
E.H. Hassan ${ }^{1}$; M.M. Farghaly ${ }^{2}$ and G.M. Solouma ${ }^{3}$ \\ ${ }^{1}$ Animal Production Department, Faculty of Agriculture, Al-Azhar University Assiut Branch, Egypt. \\ ${ }^{2}$ Animal Production Department, Faculty of Agriculture, Assiut University, Egypt. \\ ${ }^{3}$ Animal Production Department, Faculty of Agriculture, Sohag University, Egypt.
}

(Received 9/9/2014, Accepted 25/10/2014)

\section{SUMMARY}

$\mathrm{T}$ Whe current study was conducted to investigate the effect of addition green tea and tetracycline hydrochloride or both of them to growing buffalo rations on digestibility, blood metabolites and animal performance. Twelve buffalo calves of 11-13 months of age weighing $213 \pm 3.52 \mathrm{~kg}$ were divided into 4 groups of 3 animals each. Dried green tea was added to calves in basic diet (control) at levels of $0.5 \%(\mathrm{~T} 1), 1 \%$ tetracycline hydrochloride (T2), and $1 \%$ dried green tea and $1 \%$ tetracycline hydrochloride (T3) for 4 month experimental period. All animals of these groups were fed $80 \%$ of their requirements as concentrate mixture while wheat straw and alfalfa hay was given. The quantity of concentrate mixture was adjusted every month according to change in body weight (NRC, 2001). The results indicated that dietary supplementation of green tea and tetracycline, or both of them did not significantly $(p<0.05)$ affect on all nutrient digestibility, except EE digestibility was significantly $(p<0.05)$ lower in group T3 than control. No statistically significant differences were observed among the feed supplemented groups for blood proteins, namely albumin and globulin. Buffalos calves fed rations supplemented with tetracycline in $\mathrm{T} 2$ or tetracycline and green tea in $\mathrm{T} 3$ decreased significantly $(\mathrm{P}<0.05)$ serum total cholesterol as compared with those fed control and green tea rations (163.80 and 166.99 vs. 196.17 and 203.31 respectively). Also, no significant differences were observed among all treatments for ALT and AST. However, it was noticed that buffalos fed supplemented tetracycline and green tea in T3 tended to be lower by $3.5 \%$ and $7.3 \%$ for ALT and AST respectively than control group. On the other hand, performance of growing calves in terms of average daily gain, total dry matter intake and fed conversion ratio did not affected by supplemented green tea and tetracycline or both of them to rations. From the results of this study it can be concluded that incorporating green tea at a rate of $0.5 \%$ and tetracycline at a rate of $1 \%$ is Insufficient to improve digestibility and performances of growing buffalo, however mixed feed additive from green tea and tetracycline by rate $1 \%$ may be suitable for buffalo's calves, which slightly improvements were noticed.

Keywords: growing buffalo calves, green tea, tetracycline, performance, blood metabolites, nutrient digestibility

\section{INTRODUCTION}

Many farms are using antibiotics as growth promoters for improving economic and effective animal production (Wierup, 2000). According to the National Office of Animal Health (NOAH, 2001), antibiotic growth promoters are used to "help growing animals digest their feed more efficiently, get maximum benefit from it and allow them to develop into strong and healthy individuals". Although the mechanism underpinning their action is unclear, it is believed that the antibiotics suppress sensitive populations of bacteria in the intestines. Tetracyclines including oxytetracycline, tetracycline, chlorotetracycline and doxycycline, are considered the main antibiotics used in livestock production. Tetracycline are licensed for use in a wide range of livestock and can be administrated either supplemented to feed or by injection.

Antibiotic supplementation in animal feed can result in bacterial resistance in human pathogens through consumption of animal products. The European Union has banned the use of several antibiotics in animal feeds (Bowman, 1998). With the restriction or ban of dietary antimicrobial agents, we must explore new ways to improve and protect the health status of farm animals, to guarantee animal performance and to increase nutrient availability. So to produce food which is safe for human consumption, it is highly desirable to use medicinal plants or herbs and natural resources having natural 


\section{Hassan et al.}

antibiotic properties. One of medicinal plants is green tea, (Yang et al., 2003). Green tea can be used for animal feed additives to produce safe and hazard-free animal products. Medicinal plants as green tea are being suggested as effective alternatives to antibiotics (Fuller, 1989; Mohan et al., 1996).

Green tea has over 200 bioactive compounds and contains over 300 different substances (Labdar, 2010). The chemical composition of tea is multifaceted, consisting of polyphenols (catechins and flavanoids), alkaloids (caffeine, threobromine, theophylline), volatile oils, polysaccharides, amino acids, lipids, vitamin C, minerals and other uncharacterised compounds (Karori et al., 2007). The polyphenols compounds of green tea accounts for $30 \%$ to $36 \%$ weight of the water extractable materials in tea leaves and have been shown to improve body weight gain and feed efficiency in pigs (Hossain et al., 2012), cattle (Sarker et al., 2010) and broilers (Biswas and Wakita, 2001). These compounds also maintain micro flora balance and exhibit antimicrobial effects against pathogenic bacteria (Guray et al., 2011; Hara-Kudo et al., 2005). A decrease in the number of calf deaths was also observed, due to the effect of green tea in the prevention of digestive and respiratory organ diseases in calves while nursing (Ishihara et al., 2001). Green tea catechins protect the brain, liver and kidney from lipid peroxidation injury (Lin et al., 1998). Moreover Green tea polyphenoles protects against alcohol induced liver and serum lipid peroxidation (Skrzydlewska et al., 2002).

Recently, green tea has been attracting much attention because of its wide medicinal functions such as reduction of plasma total cholesterol, cholesterol ester, very-low-density lipoprotein-cholesterol and the atherogenicindex (Muramatsu et al., 1986). Gad and Zaghloul (2013) found that green tea extract improve hepatic, renal and hematological parameters and serum lipid profile as well as the ultra-structure of the liver and kidney cells.

The objectives of this study were to investigate the effects of feeding green tea and tetracycline on growth performance, nutrient digestibility, and blood metabolites of growing buffalo calves.

\section{MATERIALS AND METHODS}

\section{Animals, rations and management:}

The experiment was carried out at the research farm of Faculty of Agriculture, Al-Azhar University Assiut, Egypt. Twelve healthy buffalo calves of 11-12 months of age weighing $213 \pm 3.52 \mathrm{~kg}$ were divided into 4 groups of ( 3 animals each) according to their average live body weight. The source of green tea is china and the source of tetracycline dehydrate is Adwia company for Vet. Egypt. Supplements (green tea and tetracycline) were added to calves diet (concentrate mixture part) at levels of $0.5 \%$ green tea (T1), $1 \%$ Tetracycline (T2), and $1 \%$ Green tea and $1 \%$ Tetracycline (T3) for 4 month experimental period. The control diet consists of concentrate mixture, wheat straw and hay Alfalfa. The compositions of concentrate mixture were $50 \%$ yellow maize, $14 \%$ wheat bran, $15 \%$ linseed meal, $13.5 \%$ soybean meal, $5 \%$ molasses, $1.0 \%$ calcium carbonate, $1.0 \%$ sodium chloride, and $0.5 \%$ minerals and vitamins mixture.

The animal's requirements for CP and TDN were calculated according to NRC (2001). The concentrates mixture level was $2 \%$ while roughage level was $1 \%$ of body weight. All animals of all groups were fed $80 \%$ of their requirements as concentrate mixture while wheat straw and alfalfa hay was given ad libitum. The quantity of concentrate mixture was adjusted every month according to change in body weight (NRC, 2001). The animals were randomly allotted to experimental diets.

The ingredients and chemical composition of experimental diets are shown in Tables (1) and (2). Rations were offered twice a day and the feed orts were weighed daily through the experimental period and actual feed intake was calculated. Feed conversion ratio was calculated and expressed in terms of $\mathrm{kg}$ dry matter (DM per one-kg body weight gain. Diets were mixed daily and fed twice a day ad libitum. Calves were housed on concrete-floor in separate pens. They were fed individually in locally manufactured mangers. The calves were weighed initially and every month thereafter before morning feeding. Economic analysis of data was done using the technique of Perrin et al. (1979). Round the clock fresh and clean water was available to them. Calves were de-wormed at the start of the experiment. The study lasted for 6 months.

\section{Digestibility trials:}

Digestibility trials were conducted to determine the digestion coefficients and percentage nutrients digestibility for the four different experimental diets. Each digestibility trial was carried out using three 
buffalos calves. Each trial lasted for 12-day, the first 5-day was considered as a preliminary period followed by a 7-day collection period.

Table (1): Ingredients composition (\%) of concentrate mixture rations.

\begin{tabular}{lcccc}
\hline Item & Control & T1 & T2 & T3 \\
\hline Concentrate mixture & 71 & 70.5 & 70 & 70 \\
Wheat bran & 25 & 25 & 25 & 24 \\
Green tea & - & 0.5 & - & 1 \\
Tetracycline & - & - & 1 & 1 \\
Limestone & 2 & 2 & 2 & 2 \\
Salt & 1 & 1 & 1 & 1 \\
Minerals Mixture & 1 & 1 & 1 & 1 \\
Total & 100 & 100 & 100 & 100 \\
\hline Tl Green tea Tetracycline & T3 Green tea + Tetracycline & &
\end{tabular}

Table (2): Chemical composition of experimental rations (\%DM basis).

\begin{tabular}{cccccccc}
\hline Item & DM & OM & CP & CF & EE & NFE & Ash \\
\hline Control & 90.66 & 89.51 & 17.04 & 18.18 & 4.13 & 50.16 & 10.49 \\
$\mathrm{~T}_{1}$ & 90.52 & 89.63 & 16.92 & 17.02 & 3.94 & 51.75 & 10.37 \\
$\mathrm{~T}_{2}$ & 90.30 & 89.47 & 17.53 & 17.65 & 4.77 & 49.52 & 10.46 \\
$\mathrm{~T}_{3}$ & 90.53 & 89.43 & 16.94 & 16.83 & 4.37 & 51.29 & 10.57 \\
\hline
\end{tabular}

T1 Green tea $\quad$ T2 Tetracycline $\quad$ T3 Green tea + Tetracycline

The rations were sampled daily during the trial and the samples were composited at the end of each trial, ground through $1 \mathrm{ml}$. screen, and stored for chemical analysis. Faeces were weighed just at the time of collection and $10 \%$ of the total amount were taken and dried at $60-70{ }^{\circ} \mathrm{C}$ for $24 \mathrm{~h}$. The dried samples were mixed and ground for chemical analysis. The daily dried fecal samples from each animal were grounded through $1 \mathrm{~mm}$ mill screen openings and were saved for chemical analysis.

\section{Chemical analysis and digestion coefficients measurements:}

The chemical analysis of feeds and faeces were carried out according to the procedures of Association of Official Analytical Chemists (AOAC, 1999) using duplicate samples. The apparent digestion coefficients of nutrients were calculated by expressing the difference between the content of nutrient in both consumed feed and faeces as a percentage of its intake.

\section{Blood sampling:}

Blood samples were collected from the jugular vein monthly after the morning feeding.Blood samples were immediately centrifuged at $3000 \mathrm{rpm}$ for $20 \mathrm{~min}$. and serum was stored at $-20{ }^{\circ} \mathrm{C}$ until analysis. Serum total protein ( $\mathrm{TP} \mathrm{g} / \mathrm{dl}$ ), albumin (AL $\mathrm{g} / \mathrm{dl}$ ), alanine aminotransferase (ALT), aspartate aminotransferase (AST) and cholesterol were determined by spectrophotometer (Unico, USA) using commercial test kits (Spinreact, Spain). Serum globulin (GL g/dl) was obtained as the difference between the total protein and albumin concentration.

\section{Statistical analysis:}

Statistical analysis was carried out using general linear model (G.L.M) of SAS (2001) program, version 8.2. Differences between groups in nutrient digestibility, blood metabolites and performance were evaluated by one way ANOVA.The significance differences between treatments means were tested by Duncan Multiple Range Test (Steel and Torrie, 1980). The data were presented in mean \pm S.E.M. Level of significance was set at $\mathrm{P}<0.05$. 


\section{Hassan et al.}

\section{RESULTS AND DISCUSSION}

\section{Nutrients digestibility:}

The average values of nutrients digestibility in the experimented diets are presented in (Table 3 ). In general, the digestibility of different nutrients did not differ significantly among all treatments except those of ether extract digestibility, it was significantly $(\mathrm{P}<0.05)$ lower by about $12.77 \%$ for buffalo fed green tea and tetracycline T3 than that animal fed control rations. However, no significant differences were observed among buffalos fed control, T1 and T2 rations for EE digestibility. Also, it was noticed that there are numerical differences in CF digestibility for calves feed green tea and calves fed green tea and tetracycline treatments, which was decreased by about $15 \%$ than that buffalo fed control group. The low digestibility for $\mathrm{CF}$ and $\mathrm{EE}$ may be due to tannins contents of green tea that are known to reduce ruminal turnover, as well as rate of digestion (Reed, 1995). Similar results were confirmed by Makoto et al., (2004), who reported that whole-crop oat silage with the addition of green tea waste did not significantly affect on DM digestibility. Green tea containing high catechin may have an inhibitory effect on intestinal absorption of lipid (Ikeda et al., 1992). This may be preventing an excessive accumulation of lipid in the liver and other tissues.

Table (3): Effect of different supplements on nutrient apparent digestibility (\%) and feeding value of different rations.

\begin{tabular}{|c|c|c|c|c|c|}
\hline Items & Control & $\mathrm{T}_{1}$ & $\mathrm{~T}_{2}$ & $\mathrm{~T}_{3}$ & $\mathrm{P}$ \\
\hline DM & $82.90 \pm 0.39$ & $82.43 \pm 0.63$ & $82.74 \pm 0.34$ & $82.60 \pm 0.42$ & 0.900 \\
\hline $\mathrm{OM}$ & $64.66 \pm 0.44$ & $64.42 \pm 1.34$ & $64.31 \pm 0.63$ & $63.84 \pm 0.83$ & 0.925 \\
\hline $\mathrm{CP}$ & $75.34 \pm 1.58$ & $74.65 \pm 1.65$ & $75.30 \pm 0.65$ & $75.93 \pm 2.12$ & 0.952 \\
\hline $\mathrm{CF}$ & $54.51 \pm 3.44$ & $47.52 \pm 4.24$ & $51.16 \pm 1.92$ & $47.33 \pm 2.93$ & 0.402 \\
\hline $\mathrm{EE}$ & $83.13^{\mathrm{a}} \pm 3.69$ & $77.18^{\mathrm{ab}} \pm 1.87$ & $76.08^{a b} \pm 2.63$ & $72.51^{\mathrm{b}} \pm 2.75$ & 0.013 \\
\hline NFE & $62.35 \pm 0.75$ & $64.84 \pm 0.80$ & $63.08 \pm 1.55$ & $63.71 \pm 1.42$ & 0.534 \\
\hline TDN, \% & $61.80 \pm 0.33$ & $61.14 \pm 1.06$ & $61.67 \pm 0.92$ & $60.70 \pm 1.23$ & 0.835 \\
\hline $\begin{array}{l}\text { SV } \\
\text { Theoretical }\end{array}$ & $61.08 \pm 0.15$ & $60.74 \pm 1.06$ & $61.19 \pm 0.88$ & $60.29 \pm 1.18$ & 0.894 \\
\hline SV true & $44.73 \pm 1.18$ & $46.48 \pm 0.59$ & $45.84 \pm 1.32$ & $46.08 \pm 0.34$ & 0.621 \\
\hline
\end{tabular}

Means within row bearing different superscripts differ significantly $(p<0.05)$.

T1 Green tea T2 Tetracycline T3 Green tea + Tetracycline

The feeding value in terms of total digestible nutrients (TDN), starch value (SV) were not significant affected $(\mathrm{P}<0.05)$ for all rations.

\section{Blood metabolites:}

The data of serum parameters are summarized in (Table 4). No statistically significant differences were observed among the feed supplemented groups for blood proteins, namely albumin and globulin. The values of albumin and globulin are similar to those of other early stage ruminants such as buffalo calves (Kumar and Dass, 2006), lambs (Harton, 1992) and dairy calves (Belibasakis and Tsirgogianni, 1996). The values of albumin/globulin ratio in the present study were higher $(\mathrm{P}<0.05)$ for buffalos fed diet supplemented with green tea and tetracycline at rate of $1 \%$ (T3) than those fed diet with green tea at rate of $0.5 \%$ (T1). These results are in agreement with those of Gad and Zaghloul (2013) they reported that treatment of aged rats with green tea extract caused a significant increase in levels of total protein, albumin, globulin, albumin/ globulin $(\mathrm{A} / \mathrm{G})$ ratio. Buffalos fed rations supplemented with tetracycline in T2 or tetracycline and green tea in T3 decreased cholesterol significantly $(\mathrm{P}<0.05)$ as compared with those fed control and green tea diets (163.80 and 166.99 vs. 196.17 and 203.31 respectively). On the other hand, supplemented green tea to ration T1 did not decrease cholesterol in serum and this may attributed to the low percentage of green tea supplemented to the ration $(0.5 \%)$. However, the cholesterol value was lower in $\mathrm{T} 3$, this may be due to the higher level of green tea in the ration (1\%) that decrease absorbed cholesterol in the intestine.Hence, the decrease in total lipid and cholesterol may be due to the effect of green tea by-products on hepatic3-hydroxy-3-methylglutaryl coenzyme A reductase that is required for cholesterol synthesis in the liver (Ariana et al., 2011). Marcel and cho (2004) reported that green tea reduced cholesterols and lipids absorption in the gastrointestinal tract. Ahmed et al. (2014) reported that 
increase green tea by-products levels $(0 \%, 0.5 \%, 1.0 \%$ or $2.0 \%)$ in goats rations decreased linearly plasma glucose and cholesterol ( $\mathrm{p}<0.01$ ). Also, Han et al, (1999) and Juhel et al. (2000) found that green tea inhibit digestive lipases. Similarly, Md and Masaak (2001) found that levels of liver cholesterol, liver fat and blood serum cholesterol were significantly reduced $(\mathrm{P}<0.05)$ by green tea supplement to broilers rations. Yang et al. (2003) reported that addition of green tea by-product to chickens diets tended to decrease blood cholesterol and cholesterol content in chicken meat as compared with control, but a significant difference was not observed $(\mathrm{p}>0.05)$.

Table (4): Effect of different supplements on blood metabolites.

\begin{tabular}{lccccc}
\hline Item & Control & $\mathrm{T}_{1}$ & $\mathrm{~T}_{2}$ & $\mathrm{~T}_{3}$ & $\mathrm{P}$ \\
\hline Total protein $(\mathrm{g} / \mathrm{dl})$ & $6.92 \pm 01.10$ & $7.02 \pm 0.11$ & $6.80 \pm 0.23$ & $6.60 \pm 0.21$ & 0.389 \\
Albumin $(\mathrm{g} / \mathrm{dl})$ & $4.12 \pm 0.07$ & $4.14 \pm 0.02$ & $4.08 \pm 0.04$ & $4.17 \pm 0.01$ & 0.595 \\
Globulin $(\mathrm{g} / \mathrm{dl})$ & $2.79 \pm 0.08$ & $2.88 \pm 0.10$ & $2.71 \pm 0.24$ & $2.42 \pm 0.21$ & 0.299 \\
Al/Glo ratio & $1.49^{\mathrm{ab}} \pm 0.07$ & $1.45^{\mathrm{b}} \pm 0.04$ & $1.59^{\mathrm{ab}} \pm 0.13$ & $1.84^{\mathrm{a}} \pm 0.17$ & 0.014 \\
ALT (U/l) & $14.77 \pm 0.87$ & $14.22 \pm 0.87$ & $13.66 \pm 0.83$ & $14.22 \pm 0.87$ & 0.844 \\
AST (U/l) & $16.33 \pm 0.78$ & $15.00 \pm 1.00$ & $14.33 \pm 0.72$ & $15.22 \pm 1.70$ & 0.653 \\
Cholesterol mg/dl & $196.17^{\mathrm{a}} \pm 6.21$ & $203.31^{\mathrm{a}} \pm 10.49$ & $163.80^{\mathrm{b}} \pm 3.96$ & $166.99^{\mathrm{b}} \pm 4.87$ & 0.0003 \\
\hline
\end{tabular}

Means within row bearing different superscripts differ significantly $(p<0.05)$.

T1 Green tea T2 Tetracycline T3 Green tea + Tetracycline

No significant differences were observed among all treatments for ALT and AST. However, it was noticed that buffalos fed supplemented tetracycline and green tea in $\mathrm{T}_{3}$ tended to be lower by $3.5 \%$ and $7.3 \%$ for ALT andAST respectively than control group. Similar findings were reported by Gad and Zaghloul (2013) who supplemented green tea extracts to aged rats decreased significantly serum activities of aspartate aminotransferase (AST), alanine aminotransferase (ALT), alkaline phosphatase (ALP) and a highly significant decrease in levels of total lipids, total cholesterol and triglycerides compared to control rats.

Calves performance:

Results presented in (Table 5) shows that the differences among all groups in body weight, daily gain were not significant $(\mathrm{P}>0.05)$.However, daily gain tended to be higher in calves fed ration supplemented with green tea than other treatments. The results indicated that there were no significant differences in

Table (5): Performance of buffalo calves fed experimental diets.

\begin{tabular}{|c|c|c|c|c|c|}
\hline Item $^{*}$ & Control & $\mathrm{T}_{1}$ & $\mathrm{~T}_{2}$ & $\mathrm{~T}_{3}$ & $\mathrm{P}$ \\
\hline Feeding period(day) & 120 & 120 & 120 & 120 & - \\
\hline Initial weight $(\mathrm{kg})$ & $211.67 \pm 9.28$ & $214.00 \pm 14.47$ & $213.33 \pm 19.75$ & $213.67 \pm 18.89$ & 0.999 \\
\hline Final weight (kg) & $313.33 \pm 6.89$ & $322.00 \pm 28.93$ & $314.33 \pm 24.13$ & $315.67 \pm 35.89$ & 0.995 \\
\hline BW gain $(\mathrm{kg})$ & $101.67 \pm 7.69$ & $108.00 \pm 14.57$ & $101.00 \pm 10.39$ & $102.00 \pm 17.04$ & 0.997 \\
\hline Daily gain $(\mathrm{kg})$ & $0.847 \pm 0.064$ & $0.900 \pm 0.121$ & $0.841 \pm 0.086$ & $0.850 \pm 0.141$ & 0.977 \\
\hline \multicolumn{6}{|l|}{ Feed Intake (FI, kg/day) } \\
\hline DMI of concentrate & $3.78 \pm 0.148$ & $3.73 \pm 0.143$ & $3.76 \pm 0.144$ & $3.77 \pm 0.148$ & 0.996 \\
\hline DMI of wheat straw & $1.73^{\mathrm{ab}} \pm 0.007$ & $1.71^{\mathrm{b}} \pm 0.007$ & $1.72^{\mathrm{ab}} \pm 0.008$ & $1.75^{\mathrm{a}} \pm 0.007$ & 0.058 \\
\hline DMI of hay alfalfa & $1.29 \pm 0.282$ & $1.29 \pm 0.282$ & $1.29 \pm 0.282$ & $1.29 \pm 0.282$ & 1.000 \\
\hline Total DM intake & $6.81 \pm 0.160$ & $6.74 \pm 0.166$ & $6.78 \pm 0.164$ & $6.81 \pm 0.161$ & 0.991 \\
\hline $\begin{array}{l}\text { Feed conversion ratio } \\
\mathrm{kg} \text { DMI/kg gain) }\end{array}$ & $8.04 \pm 0.189$ & $7.50 \pm 0.185$ & $8.04 \pm 0.192$ & $8.01 \pm 0.190$ & 0.118 \\
\hline feed cost/day E.P.* & $11.64 \pm 0.27$ & $11.47 \pm 0.28$ & $11.46 \pm 0.28$ & $11.44 \pm 0.27$ & 0.953 \\
\hline Feed cost $/ \mathrm{kg} \mathrm{WG} * *$ & $13.75 \pm 0.324$ & $12.82 \pm 0.316$ & $13.75 \pm 0.328$ & $13.70 \pm 0.325$ & 0.118 \\
\hline
\end{tabular}




\section{Hassan et al.}

total DM intakes among all treatments $(6.81,6.74,6.78$ and 6.81) for control, T1, T2 and T3 respectively. On the other hand, buffalos fed ration content green tea and tetracycline was significant higher for dry matter intake of wheat straw than fed green tea (1.75 vs. 1.71). Supplemented green tea or tetracycline to rations has no effect on feed conversion ratio of growing buffalos (Table 5). Although no significant differences were observed among all groups for feed conversion ratio, numerical differences were found between $T_{1}$ and control ( 0.73 unit DM /unit gain). Results presented in (Table 5) showed that the differences in feed cost/day and feed cost $/ \mathrm{kg}$ were not significant $(\mathrm{P}<0.05)$. These results agreement with Jerome et al. (2002) who reported that neither drug nor dose significantly were in affected the rate of feed intake, average daily gain and feed conversion ratio for pigs fed concentrate mixture with different level of tetracycline.

\section{CONCLUSION}

Based on the findings among the feed additive supplementation, mixed feed additive from green tea and tetracycline may be suitable for buffalo's calves. However, supplemented green tea at rate of $0.5 \%$ and tetracyclineat rate of $1 \%$ were insufficient to make effect on digestibility or performance of growing buffalos. Further studies are required to apply higher levels of green tea or use green tea extracts and byproducts on rumen fermentation, performance and meat quality for growing buffalos.

\section{REFERENCES}

Ahmed, S.T.; J.W. Lee; H.S. Mun and C.J. Yang (2014). Effects of supplementation with green tea byproducts on growth performance, meat quality, blood metabolites and immune cell proliferation in goats. Journal of Animal Physiology and Animal Nutrition. 99: 1127-1137.

AOAC (1999). Association of Official Analytical Chemists. Official Methods of Analysis, 16th ed.: AOAC. AOAC, Gaithersburg, MD, USA.

Ariana, M.; S. Abdolhossein; A.E. Mohammad and J. Rahman (2011). Effects of powder and extract form of green tea and marigold, and $\alpha$-tocopheryl acetate on performance, egg quality and egg yolk cholesterol levels of laying hens in late phase of production. Journal of Medicinal Plants Research, 5(13): 2710-2716.

Belibasakis, N.G. and D. Tsirgogianni (1996). Effect of niacin on milk yield, milk composition and blood components of dairy cows in hot weather. Anim.Feed Sci. Technol., 64: 53-59.

Biswas, A.H. and M. Wakita (2001). Comparison of two dietary factors, green tea powderfeeding and feed restriction, influencing laying performance and egg quality in hens. Bulletin of the Faculty of Bioresources, Mie University, 25/26: 55-61.

Bouwman, G.W. (1998). Poultry nutrition.Wesselweg 32, Berneveld, The Netherlands, 49-51.

Juhel, C.; M. Armand; Y. Pafumi; C. Rosier; J. Vandermander and D. Lairon (2000). Green tea extract (AR25) inhibits lipolysis of triglycerides in gastric and duodenal medium in vitro. J. Nutr. Biochem., 11: 45-51.

Fuller, R. (1989). Probiotics in manand animals A Review. J. Appl. Bacterol., 66: 365-378.

Gad, S.B. and D.M. Zaghloul (2013). Beneficial effects of green tea extract on liver and kidney functions ultrastructure, lipid profile and hematological parameters in aged male rats. Global Veterinaria, 11(2): 191-205.

Guray, E.; N. Ocak; A. Altop; S. Cankaya; H.M. Aksoy and E. Ozturk (2011 ). Growth performance, meat quality and caecal coliform bacteria count of broiler chicks fed diet with green tea extract. Asian-Australasian Journal of Animal Sciences, 24(8): 1128.

Han, L.K.; T. Takaku; J. Li; Y. Kimura and H. Okuda (1999). Anti-obesity action of coolong tea. Int. J. Obes. Relat. Metab. Disord., 23: 98-105. 
Hara-Kudo, Y.; A. Yamasaki; M. Sasaki; T. Okubo; Y. Minai; M. Haga; K. Kondo and Y. SugitaKonishi (2005). Antibacterial action on pathogenic bacterial spore by green tea catechins. Journal of Science of Food and Agriculture, 85: 2354-2361.

Harton, G.M.J. (1992). Niacin supplement in diets for growing lambs. Small Rumin. Res., 7: 29-34.

Hossain, M.E.; Y.K. Seok and J.Y. Chul (2012). Dietary supplementation of green tea byproducts on growth performance, meat quality, blood parameters and immunity in finishing pigs. Journal of Medicinal Plants Research, 6(12): 2458-2467.

Ikeda, I.; Y. Imasato; E. Sasaki; M. Nakayama; H. Nagao; T. Takeo; F. Yayabe and M. Sugano (1992). Tea catechins decrease micellar solubility and intestinal absorption of cholesterol in rats. Biochimicaet Biophysica Acta, 1127: 141-146.

Ishihara, N.; D.C. Chu; S. Akachi1; L.R. Juneja (2001). Improvement of intestinal microflora balance and prevention of digestive and respiratory organ diseases in calves by green tea extracts. Livestock Production Science, 68: 217-229.

Jerome R.E.D.; G. Beauchamp; G.P. Martineauc; J.G. Besnera (2002). Short-term effects of in-feed supplementation of tetracyclines for disease control on feed intake pattern and growth in weaned pigs. Livestock Production Science, 76: 115-124.

Karori, S.M.; F.N. Wachira; J.K. Wanyoko and R.M. Ngure (2007). Antioxidant capacity of different types of tea products. African Journal of Biotechnology, 6(19): 2287-2296.

Kumar, R. and R.S. Dass. (2006). Effect of niacin supplementation on growth, nutrient utilization and blood biochemical profile in male calves. Asian-Aust. J. Anim. Sci., 19(10): 1422-1428.

Labdar, S.; (2010). Green tea-healthy or unhealthy? viewed 06 June 2013, from http://www.articlesbase.com/nutrition-articles/green-tea-healthy-or-unhealthy-3813575.html.

Lin, A.M.; B.Y. Chyi; L.Y. Wu; L.S. Hwang and L.T. Ho (1998). The anti-oxidative property of green tea against iron-induced oxidative stress in rat brain. Chinese Journal of Physiology, 41: 189-94.

Makoto, K.; K. Kita and H. Yokota (2004). Feeding value to goats of whole-crop oat ensiled with green tea waste. Animal Feed Science and Technology, 113: 71-81.

Marcel, W.L.K and C.H. Cho (2004). Pharmacological effects of green tea on the gastrointestinal system. European Journal of Pharmacology, 500: 177- 185.

Md, A.H.B. and W. Masaaki (2001). Effect of dietary japanese green tea powder supplementation on feed utilization and carcass profiles in broilers. Journal of Poultry Science, 38: 50-57.

Mohan, B.; R. Kadirvel; A. Natarajan and M. Bhaskaran (1996). Effect of probiotic supplementation on growth, nitrogentilization and serum cholesterol in broilers. Br. Proult. Sci., 37: 395-401.

Muramatsuk, K.; M. Fukuyo and Y. Haray (1986). Effect of green tea catechins on plasma cholesterol level in cholesterol-fed rats. J. Nutr. Sci. Vitamin nol, 32: 613-622.

National Office of Animal Health (NOAH) (2001). Antibiotics for animals. http://www.noah.co.uk/issues/antibiotics.htm Last accessed 28 October.

NRC (2001). Nutrient Requirement of Dairy Cattle, $7^{\text {th }}$ ed., National Academy of Sciences, Washington D.C.

Perrin, P.K.; D.L. Winkrnaun; E.R. Moscandi and J.R. Anderson (1979). From organic data to farmer recommendation. An Economic Training Manual Information Bulletin.27, Mexico.

Reed, J.D. (1995). Nutritional toxicology of tannins and related polyphenols in forage legumes. J. Anim. Sci., 73: 1516-1528.

Sarker, M.S.K.; S.Y. Ko; S.M. Lee; G.M. Kim; J.K. Choi and C.J. Yang, (2010). Effect of different feed additives on growth performance and blood profiles of Korean Hanwoo calves', Asian-Australasian Journal of Animal Sciences, 23: 52-60.

SAS, (2001). Statview for Windows, Version 8.2. SAS Institute, Cary, NC, USA.

Skrzydlewska, E.; J. Ostrowska; A. Stankiewicz and R. Farbiszewski (2002). Green tea as a potent antioxidant in alcohol intoxication. 111. Journal of Biological Chemistry, 277(38): 34933-34940. 


\section{Hassan et al.}

Steel, R.G. and J.H. Torrie (1980). Principles and Procedures of Statistics".A Biometrical Approach (2 nd Ed) Mc Grow- Hill Book Co., New York.

Wierup, M. (2000): The control of microbial diseases in animals: alternatives to the use of antibiotics. Int. J. Antimicrob. Agents, 14: 315-319.

Yang, C.J.; I.Y. Yang; D.H. Oh; I.H. Bae; S.G. Cho; I.G. Kong; D. Uuganbayar; I.S. Nou and K.S. Choi (2003). Effect of green tea by-product on performance and body composition in broiler chicks', Asian-Australasian Journal of Animal Sciences, 16: 867-872.

اضافة الشاى الاخضر والتتراسيكلين على هضم المكونات الغذائية وخصائص الام واداء النمو لعجول الجاموس

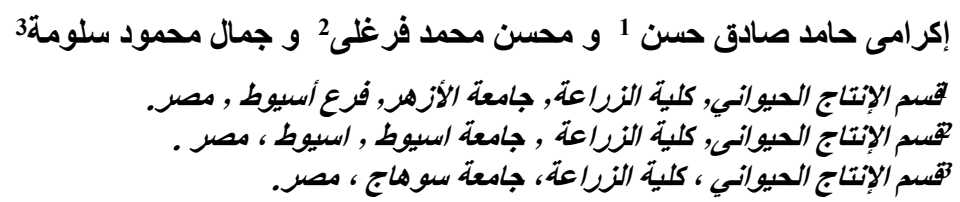

أجريت هذه الدراسة لبحث تاثير اضافة الثاى الاخضر او التتراسيكلين او كليهما لعلائق عجول الجاموس على القئ القيمة الهضمية

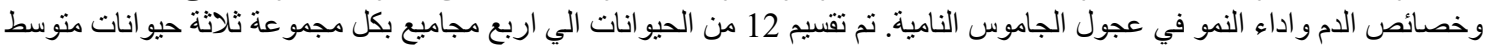

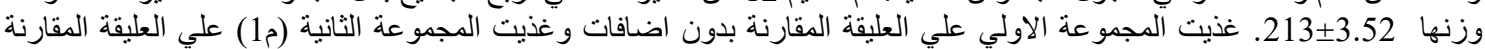

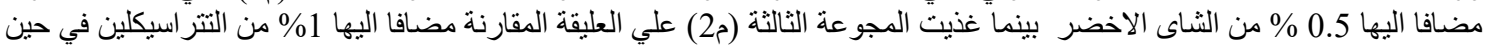

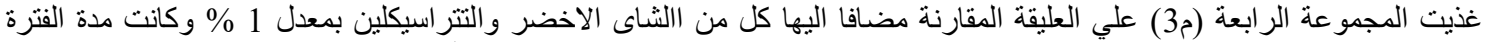

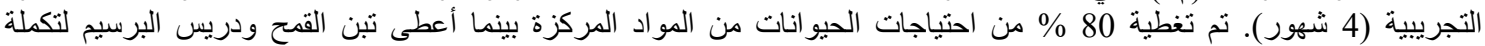

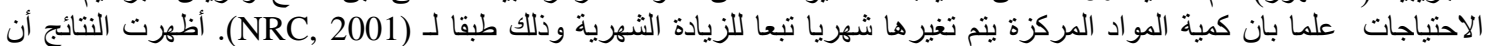

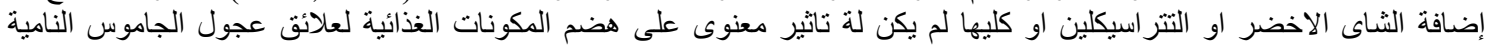
ويستسنى من ذلك هضم الدهن حيث كان منخفضا معنويا فى مجمو عة عجول الجاموس المغذاة على كل من الثناى الاخضر والتير التتر اسيكلين مقارنة بالعليقة الكنترول.

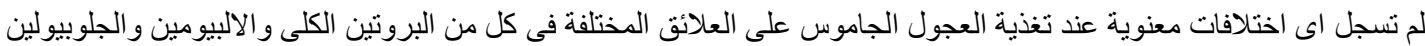

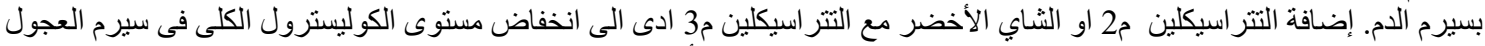

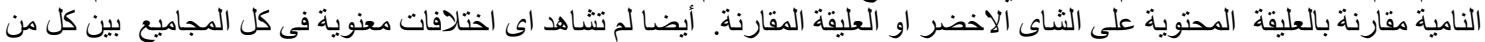

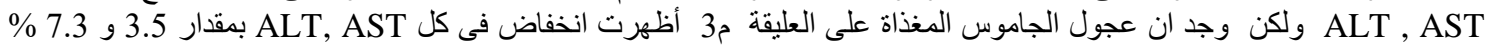

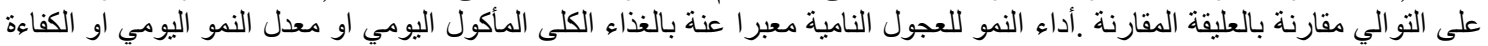

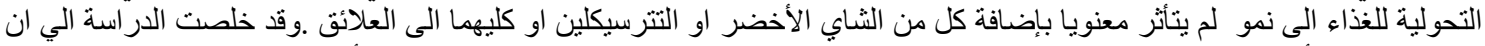

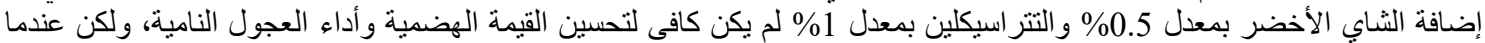

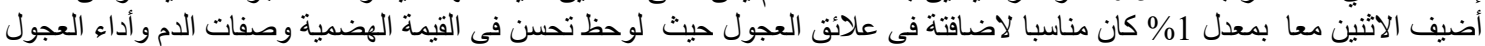

